\title{
A Review on DC-DC converters for Photovoltaic system
}

\author{
Pratapsinh G. Parmar ${ }^{1}$, Urvashi D. Patel ${ }^{2}$ \\ PG Scholar, Department of Electrical Engineering, Ganpat University, Kherva, India ${ }^{1}$ \\ Assistant Professor, Department of Electrical Engineering, Ganpat University, Kherva, India ${ }^{2}$
}

\begin{abstract}
The review of inverter with different dc-dc converter is developed with focus on low cost, high reliability and mass-production for converting electrical energy from the PV module to the grid. Various inverter topologies are presented, compared, and evaluated against demands, lifetime, component ratings, and cost. Inverter based PV system to explain electrical performance subjected to different operating conditions. PV inverter is one of the most recent and popular type of inverter founds its applications in the system based on renewable energy. By using the inverter topology with single stage and dual stage dc-dc converter harmonics in the system reduced and efficiency of the inverter enhanced significantly. This paper presents a brief literature review of the work carried out by the various researchers in this field by comparing single stage and dual stage converters with photovoltaic system.
\end{abstract}

Keywords: Photovoltaic system, single stage boost converter, dual stage boost converter, PSIM.

\section{INTRODUCTION}

Renewable energy sources (RES) are considered as a technological option for significantly contributing to the sustainable energy supply. PV energy generates electricity from solar radiation and, at present, represents one of the RES emerging technologies due to the continuous cost reduction and technological progress. The minimum element in the manufacturing of PV systems is the PV module. A typical panel is composed of 30-36 seriesconnected solar cells, with an open-circuit voltage (Voc) near $20 \mathrm{~V}$ and a short circuit current (Isc) around 3-4 A. For most applications, e.g., integration in building environment and autonomous applications, the power of one PV module is not enough. It becomes necessary to group PV modules until the desired current and voltage levels are achieved. The efficiency of commercial PV modules is about $14 \%-16 \%$. However PV systems show additional losses that are important in many cases. If not considered during the PV design phase, unreal estimations will be foreseen, and public image of PV energy could be damaged. Issues carried out on PV systems have shown losses of up to $25 \%$. Causes are varied, ranging from load mismatching (although most PV systems have maximum power point tracking (MPPT) incorporated) differences in current-voltage (I-V) characteristics, shadows, dust, losses in PV inverter, low-radiation losses, and MPPT losses [1].

Various alternatives architectures for grid connected PV system configurations are available, such as centralized module, AC module and modular configuration where the last topology perfectly fits with an intelligent PV module concept [2].

Various configurations of grid connected PV systems are available. A centralized inverter configuration is used huge number of PV modules. But, there are some severe limitations in the design of centralized inverters such as power loss for using a central MPPT, PV modules with mismatch losses due to the high voltage dc cabling connecting the PV modules with the inverter, string diode loss etc. In AC module configuration which is a simplified version of the centralized inverter topology. A single string of PV module is connected with an inverter. Each string can be applied with a separate MPPT as there is no loss attributed to string diodes. In comparison to the centralized inverter the overall efficiency is increased. In the modular configuration a common inverter is joined with multiple strings connected to individual DC-DC converter. The benefit of this modular configuration over centralized system is that each string can be controlled individually and ensure less cabling loss thereby enhancing the overall system efficiency [3].

\section{PHOTOVOLTAIC SYSTEM}

\subsection{Introduction}

Photovoltaic offer consumers the ability to generate electricity in a clean, quiet and reliable way. Photovoltaic systems are comprised of photovoltaic cells, devices that convert light energy directly into electricity. Because the source of light is usually the sun, they are often called solar cells. The word photovoltaic comes from "photo" meaning light and "voltaic" which refers to producing electricity. Therefore, the photovoltaic process is "producing electricity directly from sunlight. Photovoltaic are often referred to as PV.

\subsection{Photovoltaic cell}

A photovoltaic cell is the basic device that converts solar radiation into electricity which is made of semiconductor materials such as silicon. For solar cells, a thin semiconductor wafer is specially treated to form an electric field, positive on one side and negative on the other. When light energy strikes the solar cell, electrons are knocked loose from the atoms in the semiconductor material. If electrical conductors are attached to the positive and negative sides, forming an electrical circuit, the electrons can be captured in the form of an electric 
current that is, electricity. This electricity can then be used to power a load. A PV cell can either be circular or square in construction.

\subsection{Photovoltaic module}

Cells are arranged in a frame to form a module. The several PV cells are connected in series (for high voltage) and in parallel (for high current) to form a PV module for desired output. Separate diodes may be needed to avoid reverse currents in case of partial or total shading, and at night. The $\mathrm{p}$-n junctions of mono-crystalline silicon cells may have adequate reverse current characteristics and these are not necessary. Reverse currents waste power and can also lead to overheating of shaded cells. Solar cells become less efficient at higher temperatures and installers try to provide good ventilation behind solar panels. Each $\mathrm{PV}$ cell is rated for $0.5-0.7$ volt and a current of $30 \mathrm{~mA}$. Based on the manufacturing process they are classified as: Poly crystalline: efficiency of $12 \%$. Amorphous: efficiency of 6-8\% Life of crystalline cells is in the range of 25 years where as for amorphous cells it is in the range of 5years.

\subsection{Photovoltaic array}

The power that one module can produce is not sufficient to meet the requirements of home or business. Most PV arrays use an inverter to convert the DC power into alternating current that can power the motors, loads, lights etc. The modules in a PV array are usually first connected in series to obtain the desired voltages, the individual modules are then connected in parallel to allow the system to produce more current.

\subsection{Materials used in PV cell}

The materials used in PV cells are as follows:

1. Single-crystal silicon

2. Polycrystalline silicon

3. Gallium Arsenide (GaAs)

4. Cadmium Telluride (CdTe)

5. Copper Indium Diselenide (CuInSe2)

\subsection{Efficiency of PV cell}

The efficiency of a PV cell is defined as the ratio of peak power to input solar power. The efficiency will be maximum if we track the maximum power from the PV system at different environmental condition such as solar irradiance and temperature by using different methods for maximum power point tracking.

\subsection{Series and parallel combination of cells}

\subsubsection{Cells in series}

When two identical cells are connected in series, the short circuit current of the system would remain same but the open circuit voltage would be twice.

\subsubsection{Cells in parallel}

When two cells are connected in parallel. The open circuit voltage of the system would remain same as open circuit voltage of a single cell. But the short circuit current of the system would be twice as much as of a single cell.

\section{DC-DC CONVERTERS}

A boost converter is a dc to dc voltage converter with an output dc voltage greater than input dc voltage. This is an SMPS containing at least two semiconductors switches, diode which act as freewheeling diode two ensure a path of the current during the off state of other switch and a transistor connecting in series of the source voltage. Filters made of capacitor and inductor is used to reduce the ripple in voltage and current respectively, is used at the output stage of the converter. The basic operating principle of the converter consists of the two distinct states. In on state, switch is closed, resulting in an increase in the inductor current. In off state, switch is open, resulting in decrease in the inductor current

\subsection{Buck converter}

This is a converter whose output voltage is smaller than the input voltage and output current is larger than the input current

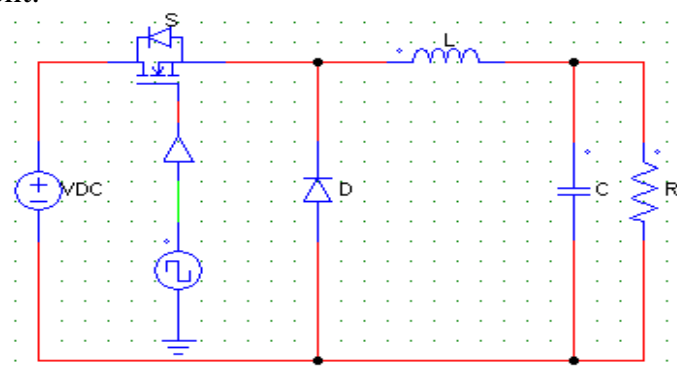

Fig 1 Buck converter

\subsection{Boost converter}

This is a converter whose output voltage is greater than the input voltage and output current is smaller than the input current

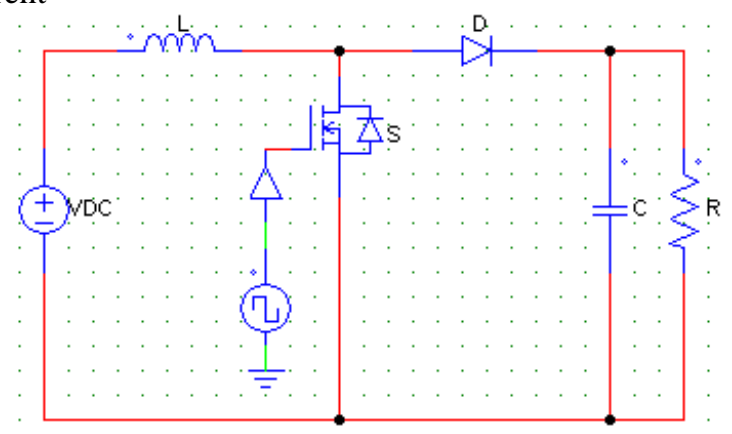

Fig 2 Boost converter

\subsection{Buck- boost converter}

The buck-boost converter is a type of DC-DC converter that has an output voltage magnitude that is either greater than or less than the input voltage magnitude.

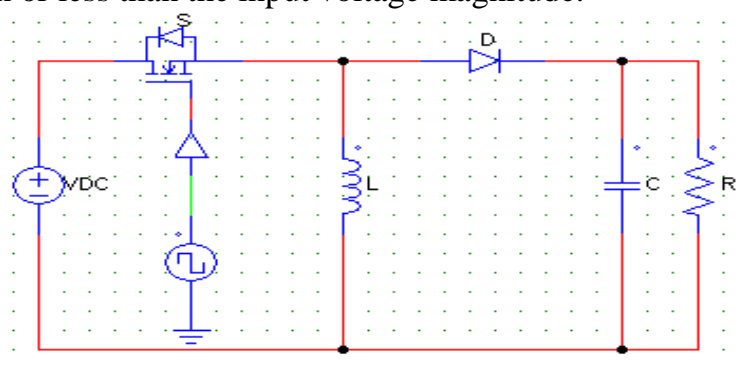

Fig 3 Buck- boost converter 


\section{SIGLE AND DUAL STAGE TOPOLOGIES}

A high step-down transformer less single-stage singleswitch ac/dc converter suitable for universal line applications (90-270 Vrms). With this direct power transfer feature and sharing capacitor voltages, the converter is able to achieve efficient power conversion, high power factor, low voltage stress on intermediate bus and low output voltage without a high step-down transformer. The absence of transformer reduces the component counts and cost of the converter [1].

Two stage conversion process increases the converter cost and reduces the efficiency of converter due to presence of more no. of semi-conductor devices. The proposed converter consists of a boost converter in parallel with a buck-boost converter. Boost converter operated in the positive half cycle and buck-boost converter in the negative half cycle. As a result we obtain a high DC output voltage from a low AC input voltage in single stage conversion [6].

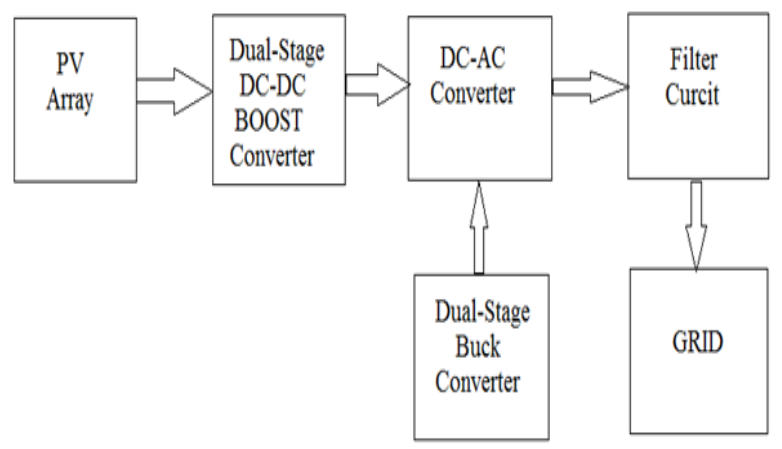

Fig 4 PV inverter with dual stage boost converter

Single-stage inverter topology for grid connected PV systems can not only boost the usually low photovoltaic $(\mathrm{PV})$ array voltage, but can also convert the solar dc power into high quality ac power for feeding into the grid while tracking the maximum power from the PV array. The PV array appears as a floating source to the grid, thereby enhancing the overall safety of the system. Necessary condition on the modulation index for sinusoidal pulse width modulated control of the proposed inverter topology has also been derived for discontinuous conduction mode operation [7].

A single-stage boost converter requires a high duty cycle which is inconvenient for MOSFET's switching; therefore a dual stage boost converter is used to get a duty cycle suitable for MOSFET switching. In conventional inverters, transformers are used to step down the grid voltage. In this paper, a transformer-less voltage divider circuit is employed to step down the grid voltage for frequency synchronization purposes. Instead of the conventional low pass LC filter, a T-LCL Converter is used at the output of the proposed inverter, which besides suppressing the harmonics also helps to maintain a constant output current [8]. A single-phase PV inverter applying a dual boost converter circuit inverter is proposed for photovoltaic (PV) generation system and PV grid connected system. Dual stage system is designed to improve integration of a Single phase inverter with Photovoltaic panel. The DC $24 \mathrm{~V}$ is converted into to $86 \mathrm{~V} \mathrm{DC}$ and then $86 \mathrm{~V}$ DC to $312 \mathrm{~V}$ DC.
The $312 \mathrm{~V}$ DC is then successfully inverted to AC $220 \mathrm{~V}$. Hence solar energy is powerfully converted into electrical energy for fulfilling the necessities of the home load, or to link with the grid [9].

Single stage AC-DC step up power converter that avoids the bridge rectification and directly converts the low AC input voltage to the required high DC Output voltage at a higher efficiency. In order to convert AC-DC we need a bridge rectifier and boost converter for step up the DC output voltage to meet the load demand. This two stage conversion process increases the converter cost and reduces the efficiency of converter due to presence of more no. of semi-conductor devices.

The proposed converter consists of a boost converter in parallel with a buck-boost converter. Boost converter operated in the positive half cycle and buck-boost converter in the negative half cycle. As a result we obtain a high DC output voltage from a low AC input voltage in single stage conversion [10].

The power loss in the transformer-less circuit is reduce which is much less than the loss incurred with a transformer. The total harmonic distortion of the output voltage is reduce which is much lower than and the efficiency of the inverter is increase. Therefore the dual stage inverter design is highly efficient, cost-effective and compact due to being transformer-less and provides a near constant current which ensures stability [12].

\section{CONCLUSION}

Different DC-DC converter used are buck, boost, buck boost converter. Due to the advancement in the power electronics it is possible to use the DC-DC converter in transformer less inverter system. Different types of DCDC converter like single stage, dual stage converter used in the transformer less system. Transformer in inverter makes system more complex, heavy weighted and has high influence on total harmonic distortion Transformerless photovoltaic grid-tie inverter used at grid to meet the future power crisis. In transformer less system with single stage boost converter total harmonic distortion (THD) of the inverter output is reduced compare to the transformer base system and the efficiency of the inverter also increases. In transformer less system with dual stage boost converter reduce total harmonic distortion (THD) of the inverter output compare to the previous system and the efficiency of the inverter also increases. It is highly efficient, cost effective as well as compact in size. It is found that in single stage boost converter the duty cycle for boost converter is large for the conventional MOSFET switching. And for buck converter the duty cycle is very small and practically not feasible to turn on the MOSFET. Therefor order to obtain convenient duty cycles, dualstage buck and dual-stage boost converter should be employed for the batter operation of the system.

\section{REFERENCES}

[1] Ahmed Abdalrahman, Abdalhalim Zekry, and Ahmed Alshazly, "Simulation and Implementation of Grid-connected Inverters", International Journal of Computer Applications (0975 - 8887) Volume 60- No.4, December 2012. 
[2] Hairul Nissah Zainudin and Saad Mekhilef, "Comparison Study of Maximum Power Point Tracker Techniques for PV Systems", Proceedings of the $14^{\text {th }}$ International Middle East Power Systems Conference (MEPCON'10), Cairo University, Egypt, December 1921, 2010, Paper ID 278.

[3] T. K. Kwang, S. Masri, "Single phase grid tie inverter for photovoltaic application," Proc. IEEE Sustainable Utilization and Development in Engineering and Technology Conf., pp. 23-28. Nov 2010.

[4] K. Srinivas, M.V.Praveen reddy "New topologies for Transformerless Single-Stage AC/DC Converter" International Journal Of Engineering And Computer Science ISSN:2319-7242 Volume 2. Issue 10 October 2013 Page No. 3008-3014

[5] T. Abdelkrim, K. Ben seddik, B. Bezza, K. Benamrane, Aeh. Benkhelifa "Experimental Study of Boost Converter Based PV Energy System" World Academy of Science, Engineering and Technology International Journal of Electrical, Computer, Energetic, Electronic and Communication Engineering Vol:7, No:12, 2013

[6] Vimal M. Vaniya, Jaydeep G. Gajipara Prof. Jayanti A. Jadav "Single Phase PWM Inverter With Close Loop Dc-Dc Boost Converter For Solar Application" International Journal of Engineering Research \& Technology (IJERT) Vol. 2 Issue 5, May 2013

[7] Sameer Ahmed Khan Mojlish "Design of a Photovoltaic Grid-Tied Inverter Employing a Dual-Stage Boost Converter and a Transformer-Less Step-Down Circuit" " International Journal of Engineering Research \& Technology (IJERT) May - 2014.

[8] Smt. Sudha Bhutada, Dr. S.R. Nigam "Single Phase PV Inverter Applying a Dual Boost Technology" International Journal of Scientific Engineering and Technology ISSN : 2277-1581 Volume No.4 Issue No.6,01 June 2015

[9] S Kumar K, S.V. Sivanagaraju, Rajasekharachari k. "Single stage ac-dc step up converter using boost and buckboost converter" International Journal of Advanced Research in Electrical, Electronics and Instrumentation Engineering Vol. 2, Issue 9, September 2013.

[10] Sachin Jain and Vivek Agarwal "A Single-Stage Grid Connected Inverter Topology for Solar PV Systems With Maximum Power Point Tracking" IEEE transactions on power electronics, vol. 22, no. 5, september 2007.

[11] Omar Abdel-Rahim, Mohamed Orabi, Emad Abdelkarim, Mahrous Ahmed and Mohamed Z. Youssef "Switched Inductor Boost Converter for PV Applications" IEEE Etransactions on power electronics 2012.

[12] Zheng Zhao1, Ming Xu, Qiaoliang Chen, Jih-Sheng Lai, Younghoon Cho “ Derivation of Boost-Buck Converter Based High-Efficiency Robust PV Inverter” IEEE 2010

[13] Sonima Antony S. Paul Sathiyan "Design and Simulation of Boost Converter with Input Ripple Cancellation Network" IEEE transactions on power electronics, 2015.

[14] Abhishek Shevde, Shivendra Singh Thakur, Sudheer Padmakar Phulambrikar "Performance Analysis of Techniques Used For Designing Of Closed Loop Dc-Dc Boost Converters" International Journal of Engineering Research \& Technology (IJERT) Vol. 1 Issue 10, December- 2012

[15] Brijesh M. Patel, Kalpesh J.Chudasma, Hardik A.Shah "Simulation of Single Phase Inverter using PSIM Software for Solar P.V. System give Constant Output Voltage at Different Solar Radiation" International Journal of Emerging Trends in Electrical and Electronics (IJETEE ) Vol. 4, Issue. 1, June-2013 